\title{
Review \\ Nano-Based Drug Delivery and Targeting to Overcome Drug Resistance of Ovarian Cancers
}

\author{
Melayshia McFadden ${ }^{1,+}$, Santosh Kumar Singh ${ }^{1,+}$, Gabriela Oprea-Ilies ${ }^{2}$ and Rajesh Singh $1,3, *$ (D) \\ 1 Department of Microbiology, Biochemistry and Immunology, Morehouse School of Medicine, \\ Atlanta, GA 30310, USA; mmcfadden@msm.edu (M.M.); sksingh@msm.edu (S.K.S.) \\ 2 Department of Pathology \& Laboratory Medicine, Winship Cancer Institute, Emory University School of \\ Medicine, Atlanta, GA 30322, USA; goprea@emory.edu \\ 3 Cancer Health Equity Institute, Morehouse School of Medicine, Atlanta, GA 30310, USA \\ * Correspondence: rsingh@msm.edu \\ + These authors have an equal contribution.
}

check for updates

Citation: McFadden, M.; Singh, S.K.; Oprea-Ilies, G.; Singh, R. Nano-Based Drug Delivery and Targeting to Overcome Drug Resistance of Ovarian Cancers. Cancers 2021, 13, 5480. https://doi.org/10.3390/ cancers 13215480

Academic Editor: Sudip K. Das

Received: 27 August 2021

Accepted: 28 October 2021

Published: 31 October 2021

Publisher's Note: MDPI stays neutral with regard to jurisdictional claims in published maps and institutional affiliations.

Copyright: (c) 2021 by the authors. Licensee MDPI, Basel, Switzerland. This article is an open access article distributed under the terms and conditions of the Creative Commons Attribution (CC BY) license (https:// creativecommons.org/licenses/by/ $4.0 /)$.
Simple Summary: Ovarian cancer (OvCa) is a prominent cause of cancer death in women due to missed early signs and late diagnoses. Once a woman is diagnosed with OvCa, the standard treatment is surgery to remove the tumor, followed by chemotherapy. Many women go into remission after treatment, but there is always a strong possibility that the cancer will return. If the cancer returns in less than 6 months, the patient is considered platinum-resistant and undergoes a new treatment plan. Drug resistance occurs when the cancer cells become resistant to the administered drug during initial chemotherapy, causing the drug to become ineffective. This is a considerable challenge in the cancer field, and many researchers are looking for strategies to overcome this drug resistance. However, nanotechnology, natural products, and RNA interference therapy are strategies that can enhance cancer therapy to overcome drug resistance in cancer cells.

Abstract: Ovarian cancer (OvCa) is a destructive malignancy due to difficulties in early detection and late advanced-stage diagnoses, leading to high morbidity and mortality rates for women. Currently, the quality treatment for OvCa includes tumor debulking surgery and intravenous platinum-based chemotherapy. However, numerous patients either succumb to the disease or undergo relapse due to drug resistance, such as to platinum drugs. There are several mechanisms that cause cancer cells' resistance to chemotherapy, such as inactivation of the drug, alteration of the drug targets, enhancement of DNA repair of drug-induced damage, and multidrug resistance (MDR). Some targeted therapies, such as nanoparticles, and some non-targeted therapies, such as natural products, reverse MDR. Nanoparticle targeting can lead to the reversal of MDR by allowing direct access for agents to specific tumor sites. Natural products have many anti-cancer properties that adversely regulate the factors contributing to MDR. The present review displays the current problems in OvCa treatments that lead to resistance and proposes using nanotechnology and natural products to overcome drug resistance.

Keywords: ovarian cancer; nanoparticles; targeted drug delivery; drug resistance

\section{Introduction}

In the developed world, ovarian cancer (OvCa) is one of the leading causes of cancer deaths among women. In the United States, approximately 1 in 78 women will develop OvCa in their lifetime; it is mainly diagnosed in women aged 64 years or older [1,2]. High-grade serous ovarian cancers, which account for $68 \%$ of OvCa cases, are clinically aggressive neoplasms that develop from the ovarian surface' epithelium. High-grade serous OvCa is usually diagnosed at a late and advanced stage and has the worst prognosis [3]. Therefore, screenings and early detection provide the opportunity for effective treatment. However, the symptoms associated with OvCa are often vague and may be 
dismissed because they are similar to the effects of the cyclic hormonal changes that occur naturally within the body $[4,5]$. Current treatment options include combinations of tumor debulking surgery, chemotherapy, and radiation therapy. Advanced treatment options include hormone therapy and targeted therapy [6]. Even with treatment, a substantial proportion of advanced OvCas will develop resistance within 18 months [7,8]. Mechanisms of drug resistance include drug inactivation, multi-drug resistance (MDR), alterations of drug targets, and enhanced DNA repair [9]. However, the most common mechanism of drug resistance in OvCa is the stimulation of ATP-dependent membrane efflux pumps, especially Multidrug resistance protein 1 (MDR1), also known as P-glycoprotein (P-gp) or $\mathrm{ABCB} 1$ [10-15]. Understanding these mechanisms can lead to advancements in the treatment of OvCa by using strategies like nanoparticles that can target and reverse MDR by allowing direct access of drugs to specific tumor sites. Furthermore, natural products can also reverse MDR due to their anti-cancer properties. In this review, we present the current problems of OvCa treatments, outline the various mechanisms involved in $\mathrm{OvCa}$ drug resistance, and propose the use of nanotechnology and natural products to overcome OvCa drug resistance.

\section{Treatments of OvCa}

\subsection{Tumor Debulking Surgery}

Once a patient is diagnosed with $\mathrm{OvCa}$, they undergo tumor debulking surgery to determine the stage of the disease and the cancer prognosis [16]. The staging assessment by surgical pathologic degrees is accomplished by following the International Federation of Gynecology and Obstetrics (FIGO), where a 5-year survival rate between 90\% and 10\% is determined based on stages I, II, III, and IV $[17,18]$. There are three broad classifications of prognostic factors for OvCa: the tumor, the patient, and the clinical interventions [19]. According to the Gynecologic Oncology Group, optimal cytoreduction is defined as a residual tumor of less than $1 \mathrm{~cm}$ after surgery and suboptimal cytoreduction as resulting in any larger residual tumor [20-22]. Such measurements are subjectively determined after surgery. If optimal debulking is achievable, it is preferable to perform primary surgery, but primary surgery should be avoided if there is a probability of suboptimal debulking [23-27]. For advanced stages of cancer (III and IV), complete cytoreduction is often not possible. Patients who are too ill or have inoperable lesions are treated with three cycles of neoadjuvant chemotherapy. If there is a response to the chemotherapy, an interval debulking surgery will be conducted, followed by six cycles of chemotherapy [28]. When completing tumor debulking surgery, the ultimate goal is the resection of all residual diseases, whether performed primarily or secondarily. However, recurrence occurs in $75 \%$ of patients despite an initial response. The remaining objective is to find an alternative approach to treat OvCa.

\subsection{Chemotherapy}

After surgery, chemotherapeutic drugs are used to treat patients. The most common agents for the treatment of OvCa are carboplatin and cisplatin [29]. In the early 1980s, carboplatin was introduced as an equivalent of cisplatin due to its similarities in response rate and survival outcomes. However, carboplatin is preferred over cisplatin due to the potential for nephrotoxicity, ototoxicity, and nausea or vomiting seen with cisplatin [30-34]. Carboplatin is an alkylating agent that inserts platinum into DNA to form crosslinks. The resulting structural distortion of the DNA triggers a signaling cascade resulting in apoptosis $[35,36]$. Patients who relapse within 6 months of platinum treatment are considered drug-resistant, and they have a median survival time of less than a year [37]. However, the standard treatment of platinum-resistant $\mathrm{OvCa}$ is non-platinum single-agent chemotherapy, such as paclitaxel (PTX). In the 1990s, PTX was the most efficient chemotherapeutic agent for patients with relapsed platinum-resistant OvCa [38]. PTX is cell cycle-specific and binds to $\beta$-tubulin, which causes microtubule stabilization, $\mathrm{G}_{2}-\mathrm{M}$ arrest, and apoptosis. However, resistant cancer cells treated with PTX remain in mitosis until the drug clears and then 
continue proliferation, resulting in PTX resistance $[39,40]$. Currently, it is not possible to predict a patient's response to chemotherapy, and it is unlikely for a patient to advance from further chemotherapy after failing two lines of treatment due to the inevitable toxicities and side effects associated with treatment.

\subsection{PARPi Frontline Therapy for Ovarian Cancer}

Decades of research have investigated drug resistance and targeted therapy for $\mathrm{OvCa}$ patients. After initial surgery and chemotherapy, there is often no evidence of disease; however, most patients experience recurrence [41]. In light of such resurgence following initial therapy and understanding and deciphering the situation at the molecular level, poly-ADP-ribose polymerase (PARP) inhibitors have been developed. A recent report established that olaparib, niraparib, or rucaparib [41,42] reduced DNA repair in cancers with a BRCA gene mutation, leading to cancer cell death. Since empirical findings support an anti-tumorigenic role, several clinical trials have been conducted that display promising progression-free survival (PFS) (NCT04573933). According to the phase two trial of rucaparib, patients with platinum-sensitive, high-grade ovarian carcinoma with a BRCA mutation (germline or somatic) and high chromosomal loss of heterozygosity have increased PFS [43]. The FDA has approved this drug for treating advanced OvCa. Another breakthrough FDA approval is for olaparib monotherapy, given to OvCa patients who received chemotherapy and have a suspected germline BRCA mutation. Furthermore, the European Medicines Agency (EMA) approved olaparib for high-grade serous epithelial ovarian, fallopian tube, or primary peritoneal cancer with a germline or somatic mutation that responds to platinum therapy [43]. Moreover, scarcity of tumor suppressor genes such as ATR, ATM, PALB2 [43], and PTEN [44] also confers susceptibility to PARP inhibitors. Growing evidence suggests that the loss of PTEN increases chromosomal instability [45] and replication fork collapse [46] in most cancers. In contrast, both BRCA mutant and BRCAness cancers are resistant to PARPi therapy $[43,46]$, which leaves the unanswered question of how cancer cells present defensive measures.

\subsection{Chimeric Antigen Receptor-Modified T (CAR-T) Cell Therapy}

Despite the initial response to chemotherapy, OvCas generally recur, and most patients have low median survival rates [47]. In this context, an effective therapeutic approach is urgently required to achieve the long-term survival of OvCa patients [48]. The most recent clinical approach for cancer treatment includes adoptive $\mathrm{T}$ cell transfer (ACT). In this therapy, the patient's T cells and natural killer cells are isolated, modified, and expanded ex vivo to achieve target immune response and eliminate cancer cells. Based on the current literature, the ACT is classified into three forms: tumor-infiltrating lymphocytes (TILs), $\mathrm{T}$ cell receptor (TCR)-T cells, and chimeric antigen receptor (CAR)-T cells [49]. The use of CAR-T engineered T cells is a promising treatment for OvCa [50] and hematological tumors [51,52]; however, its limitations are side effects and related toxicities. Methods to construct CARs include viral and non-viral transduction [48]. Cumulative evidence suggests that non-viral strategies such as liposomal-mediated, mRNA-mediated, and transposase system-mediated gene transfer have a lower risk of complication and are easier to produce than viral approaches [47]. Targeting solid tumors is more challenging due to their histopathological features, extensive vascular leakage, T-cell trafficking, and infiltration into tumor sites. This impairment occurs due to an enhanced permeability and retention (EPR) effect, heterogeneity [53], aberrant vasculature [54], and a hypoxic and immunosuppressive tumor microenvironment [55]. Nevertheless, various CAR-T biological effects are implicated in cancers, including OvCa $[48,56]$. Clinical trials conducted for CAR-T therapy of OvCa are mainly in the early phases. Furthermore, the targeting of various antigens also has excellent potential in treatment. CAR-T has a high affinity for cell surface antigens; however, T-cell antigen receptor (TCR)-T recognizes the intracellular and surface antigens presented by major histocompatibility complex (MHC) molecules [57]. Thus, CAR-T cell therapy could be developed as an alternative treatment for OvCa. 


\section{Mechanisms of Drug Resistance}

The drug resistance of tumor cells develops due to various factors, including the inactivation and alteration of drugs, DNA repair augmentation, and multidrug resistance (MDR) [9]. A schematic presentation of the MDR mechanism is shown in Figure 1.

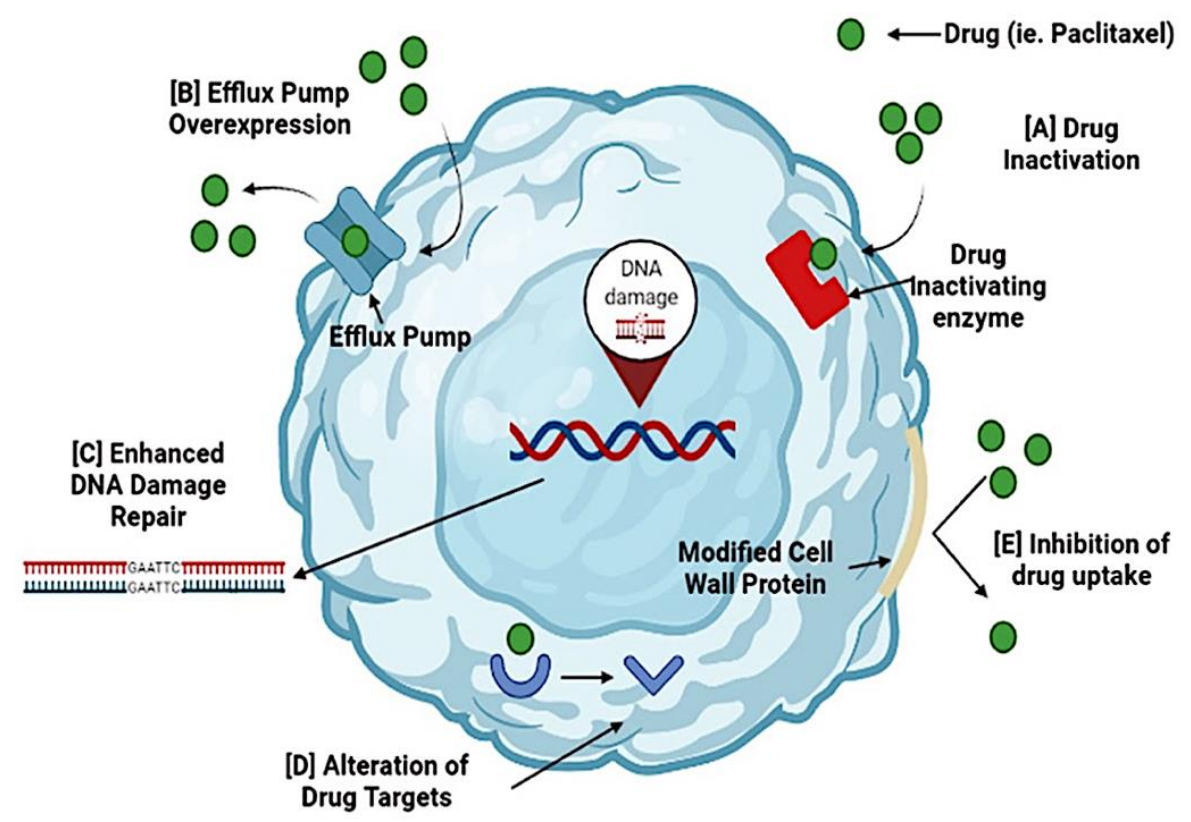

Figure 1. Mechanisms of drug resistance in ovarian cancer. Cancer cells can become resistant to the administered drug during chemotherapy. Several mechanisms cause resistance to chemotherapy. (A) Activation of a drug occurs when resistance genes (MDR) code for enzymes that chemically modify the drug. (B) Efflux pump overexpression inhibits the accumulation of a chemotherapeutic drug. (C) Enhanced DNA damage repair is triggered by DNA repair mechanisms, nucleotide excision repair, and homologous recombination. These processes reverse drug damage and increase drug resistance. (D) Alteration of drug targets occurs because chemotherapeutic drugs have specific targets, and changes may render the drug ineffective. (E) Inhibition of drug uptake occurs due to modifications in the cell wall proteins, preventing drugs from entering the cell. By targeting these resistance mechanisms, cancer cells can become sensitive to the drugs and increase their effectiveness.

\subsection{Drug Inactivation}

For some drugs to have clinical efficacy, they must avoid metabolism. Advanced OvCas often develop resistance to platinum treatment via drug inactivation. This occurs when metallothionein and the thiol glutathione switch on a detoxification system and reduce the damage to cancer cells [58,59]. Furthermore, the tumor suppressor gene p53 is involved in drug inactivation. The gene $\mathrm{p} 53$ has the potential to maintain the homeostasis and genomic integrity of the target genes. Gene p53 participates in many cellular processes such as activation of cell cycle arrest, apoptosis, and DNA repair mechanisms in cancers, including OvCa [60]. However, if p53 is mutated or deleted, apoptosis is inhibited, and drug resistance occurs [61]. Drug resistance occurs because p53 acts as a homotetrameric transcriptional factor, and its mutations lead to three different phenotypes: loss of function (LOF), dominant negative (DN), and gain of function (GOF). LOF is the leading result from mutations and simply means that there is a loss of the functions that the wild-type (WT) p53 possessed. Missense mutations of p53 can cause a DN effect, causing WT p53 to lose transcriptional activity or gain novel oncogenic functions or GOF mutants. This GOF effect has been seen quite often in previous studies that demonstrated the transcriptional dependence between ABCB1 and p53 [62]. Overall, mutated p53 will disable cells from defending themselves against carcinogenesis and promote cancer cells to undergo proliferation, drug resistance, and metastasis [61,63]. 


\subsection{Alteration of Drug Targets}

PTX resistance can occur in OvCas due to alterations of drug targets (e.g., a mutation in $\beta$-tubulin). Microtubules are created by $\alpha$ - and $\beta$-tubulin heterodimers associating together in a head-to-tail fashion. PTX binds to $\beta$-tubulin, leading to microtubule stability and polymerization. Thus, blocking the cell cycle, especially the mitosis phase, induces apoptosis $[64,65]$. However, $\beta$-tubulin mutations cause the opposite effect in microtubule dynamics and stability, erode the interactions between PTX and $\beta$-tubulin, and increase resistance to PTX [66-71].

Along with the alteration of drug targets, drug resistance can occur through altering the process of drug activation. The resistance mechanism is thought to be associated with the loss of phosphatase and tensin homolog (PTEN) function, cell cycle inhibition, co-expression of growth factor receptors, and upregulation of the PI3K/Akt pathway $[59,72,73]$. Overexpression of the PI3K/Akt pathway downregulates PTEN expression and increases resistance to PTX [74-76].

\subsection{DNA Damage Repair}

Chemotherapeutic agents may directly or indirectly damage the DNA of cancer cells. However, cancer cells can recognize the damaged DNA and repair it [9]. For example, for many years, treating OvCa was solely performed by using chemotherapy with platinum-based drugs like carboplatin, which causes DNA crosslinks, leading to apoptosis and cell death. However, prolonged exposure of OvCa to platinum drugs leads to resistance due to nucleotide excision repair, DNA repair mechanisms, and homologous recombination [9,59,77]. In OvCas, these DNA repair systems are primarily involved in reversing platinum damage and increasing drug resistance. Nevertheless, inhibition of the DNA repair systems sensitizes cancer cells to these drugs, thus increasing the potency of chemotherapy. Therefore, in cancer cells, the efficacy of these chemotherapeutic agents is dependent on the inhibition of the DNA repair systems.

\subsection{Multidrug Resistance}

A challenge in cancer treatment is multidrug resistance (MDR), which provides cancer cells with the capacity to survive against exposure to an extended range of anti-cancer drugs [78]. MDR can develop by several mechanisms, including decreased drug uptake, increased detoxification, or increased efflux by upregulation of ATP-binding cassette (ABC) transporter genes $[39,79]$. The MDR to chemotherapeutic drugs in cancer cells is mediated through a mechanism involving P-glycoprotein (P-gp, or MDR1), multidrug resistanceassociated protein 1 (MRP1, or ABCC1), or breast cancer resistance protein (BCRP, or ABCG2) $[9,80]$. P-gp, which is required for the normal passage of chloride ions in and out of the cell, binds to chemotherapeutic drugs such as PTX. This binding results in ATP hydrolysis at the nucleotide binding site, leading to a change in configuration and to efflux out of the cell, thus rendering them inactive [10-12,81]. Another class of efflux pumps that mediates MDR in cancer cells toward taxanes is the MRP family, referred to as adenosine triphosphate-binding cassette $C$ group $(A B C C)$ transporter proteins $[39,77,82]$. One such member is MRP1, an ABC transporter that effluxes drugs and organic anions across the plasma membrane. In the absence of MDR1 or P-gp expression, MRP1 provides drug resistance for various types of cancer. Another carrier, breast cancer resistant protein, which is coded by ABCG2, is overexpressed in OvCas [83]. Moreover, extracellular vesicles (EVs) are of growing interest as modulators of drug resistance within the tumor microenvironment. These act as cargo carriers between tumor cells and stromal cells. EVs are small in size (30-150 nm), involved in metastasis, and can direct the function of a cell by carrying nucleic acids, proteins, or lipids [84]. We may overlook various facets of EVs that result in the modulation of drug resistance. Based on recent studies, identifying a vesicular component, such as miR21, which contributes to taxane resistance, might be helpful to develop a therapeutic option for OvCa by interfering with drug uptake [85]. Overall, these classes of efflux pumps, alone or in combination, reduce the cancer cells' sensitivity to 
the chemotherapeutic drugs, leading to the failure of the OvCa treatment. Therefore, to overcome these challenges, strategies to use monoclonal antibodies or chemical compounds that bind to and render inactive these efflux pumps have been developed. Secondly, drug combinations were prepared to allow higher doses of chemotherapy drugs, and alterations to the structures of chemotherapy drugs were made. The objective was to make the drug incapable of binding to the efflux proteins. Finally, strategies have been used to inactivate the MDR genes at the transcriptional level by targeting their mRNAs [86]. These strategies often involve the use of natural products or nanotechnology.

\subsection{Overcoming Resistance to the Checkpoint Blockade}

The elimination of cancer cells through the immune system has been a dream for cancer biologists. Traditional methods to reduce cancer stimulate the immune system with vaccines, dendrite cell activation, or immunostimulants. Despite the use of this defense mechanism, tumor cell elimination remains a challenge. The cancer cells escape immunity through loss of tumor cell recognition by T-cells, creation of an immunosuppressive microenvironment, or modulation of the immune checkpoint [63]. A critical element of the checkpoint mechanism is represented by the programmed cell death protein 1 (PD-1) and programmed cell death-ligand 1 (PD-L1) interaction, which results in T-cell deactivation, preventing healthy cells from being targets of T-cell-toxicity [63]. Among the several strategies to tackle cancer cells through the immune system is to use the checkpoint inhibitors that target the immune escape mechanisms and restore the T-cells of the host to total anti-tumor activity. Although the blockade of PD-1/PD-L1 requires reactivation and clonal proliferation of the T-cells present in the tumor microenvironment, failure of the checkpoint inhibitors may lead to (1) insufficient generation of anti-tumor T cells, (2) inadequate function of tumor-specific T cells $[66,67]$, or (3) impaired formation of T-cell memory $[64,68]$. Approved checkpoint inhibitors include nivolumab, pembrolizumab, and cemiplimab for PD-1; atezolizumab, durvalumab, and avelumab for PD-L1; and ipilimumab for CTLA-4 [69]. Despite using these potent and broadly active inhibitors of PD-1/PD-L1, most patients do not respond or develop tumor progression or recurrence after a secondary response [70]. Clinical trials are underway to overcome the resistance toward checkpoint inhibitor therapy by evaluating a combination of checkpoint inhibitors along with targeted agents, cytotoxic chemotherapy, or radiation.

\section{Natural Products as Modulators to Reverse MDR}

In addition to current advanced technologies, natural products from various sources are being evaluated for cancer therapy. Natural products used for cancer therapies have low toxicity and are well-tolerated in the human body [87-90]. They exhibit anti-cancer activities via various mechanisms of action (Table 1). In this context, we provide information on several phytochemicals, including alkaloids, flavonoids, and terpenes, as modulators of MDR.

Table 1. Mechanisms of action of natural products against OvCa cells.

\begin{tabular}{cccc}
\hline Natural Product & Cell Type & Mechanism of Action & Reference \\
\hline Piperine & OVCAR-3 cells & $\begin{array}{c}\text { Induces } \mathrm{G}_{2} / \mathrm{M} \text { phase cell cycle arrest and } \\
\text { caspase activation and inhibits cell migration } \\
\text { and the PI3K/Akt/GSK3 signaling pathway }\end{array}$ \\
\hline Flavonoid & PA-1 cells & $\begin{array}{c}\text { Decreases viability; induces apoptosis; decreases } \\
\text { Bcl-2 and Bcl-xL; and increases caspase-3, } \\
\text { caspase-9, Bid, Bad, Bax, and cytochrome c }\end{array}$ \\
\hline Curcumin & Cisplatin-resistant OvCa cells & $\begin{array}{c}\text { Induces } \mathrm{G}_{2} / \mathrm{M} \text { cell-cycle arrest and increases } \\
\text { apoptosis and phosphorylation of p53 }\end{array}$ & $\begin{array}{c}\text { Induces ROS generation and apoptosis and } \\
\text { activates the autophagy pathway }\end{array}$ \\
\hline RES & OVCAR-3 cells & $\begin{array}{c}\text { Induces apoptosis by decreasing expression of } \\
\text { Bcl-2 and increasing expression of Bax }\end{array}$ \\
\hline Thymoquinone & SKOV-3 cells & [95]
\end{tabular}




\subsection{Alkaloids}

Piperine

Piperine is a natural alkaloid isolated from the long and black pepper species Piper longum and Piper nigrum. Piperine possesses health properties, such as antioxidant, antiinflammatory, antimicrobial, neuroprotective, and anti-cancer properties [91,96]. Against human OVACAR- 3 cells, piperine induces cell cycle arrest in the $G_{2} / M$ phase, caspase activation, and cell migration inhibition of the PI3K/Akt/GSK3 $\beta$ signaling pathway [91]. Furthermore, piperine affects diverse signaling molecules and pathways associated with cancer cell growth and survival by targeting PI3K/Akt, MAPK, and STAT3 $[97,98]$. These results suggest that, for these cells, piperine exerts anti-cancer effects involving apoptosis induction and cell cycle arrest. Piperine is a promising agent to increase the sensitivity of cytotoxic drugs such as PTX and in targeting the drug resistance mechanisms in OvCa cells [99]. Based on clinical trial data, piperine delays prostate cancer progression, smoldering multiple myeloma (SMM), and monoclonal gammopathy of unknown significance (MGUS) when given in combination with curcumin (NCT04731844). Thus, piperine should be considered as a potential anti-cancer agent to improve the effectiveness of therapy for cancer patients.

\subsection{Flavonoids}

Flavonoids, including flavones, flavonols, isoflavones, flavanols, flavanonols, flavanones, and chalcones, are the most utilized and analyzed natural products in cancer research [100]. This is due to their capacity to reverse MDR by killing resistant cancer cells or becoming re-sensitized to anti-cancer drugs. The flavonoids fisetin, chrysin, quercetin, kaempferol, baicalein, rutin, and icariin, as well as iso-flavonoids, genistein, etc. and biochanin A reverse MDR by inhibiting the efflux effects of ABC transporters [101].

\subsubsection{Curcumin}

Curcumin is a mixture of curcuminoids derived from the Indian spice turmeric [102]. Curcuminoids are notable for their anti-cancer, anti-inflammatory, antioxidant, and antiviral properties [103-107]. Curcumin is commonly used to circumvent MDR to various anticancer agents [86]. By inhibiting the functions of ABC transporters P-gp, MRP1, and ABCG2, it restores drug sensitivity for various cancer cells [102,108-111]. Furthermore, in cisplatin-resistant OvCa cells, curcumin induces cell cycle arrest in the $G_{2} / \mathrm{M}$ phase by increasing the apoptosis and phosphorylation of p53 [93]. However, curcumin is lipophilic and highly insoluble, so it has poor bioavailability and is efficient only in high doses. Rapid metabolism is a major problem encountered by using this and other natural products $[108,112]$. This natural product has minimal toxicity, as it and other flavonoids are used as dietary supplements. However, due to its lipophilic characteristics, it often requires a vehicle to assure its bioavailability.

Curcumin has been extensively studied in various models for a wide range of human diseases, including cancer. Animals receiving curcumin in combination therapy for cancer have longer median survival times [113,114]. For patients who relapse after surgery, curcumin prevents prostate cancer cell proliferation by blocking the enzymes needed for cell growth (NCT02064673). Many clinical trials have been completed and are ongoing on its safety and efficacy. Indeed, 72 trials have been conducted with curcumin; some of the ongoing clinical trials on curcumin are in phase three (prostate cancer, NCT03769766) or phase one (breast cancer, NCT03980509). Thus, curcumin shows promise for preventing and treating various cancers, including OvCa.

\subsubsection{Resveratrol}

Resveratrol (RES) is a polyphenol found in grapes, red wine, pines, peanuts, mulberries, and various products derived from other plant species. RES exerts anti- or pro-oxidant effects, binds to and modulates various molecular targets, inhibits tubulin polymerization, and induces apoptosis via cell cycle arrest at the $\mathrm{G}_{2}-\mathrm{S}$ checkpoint [115-120]. In a study of 
autophagy, RES-treated OVCAR-3 cells induced the generation of reactive oxygen species (ROS) and apoptosis [94]. RES has exceptional anti-cancer properties, and its pharmacokinetics, metabolism, and toxicity have been evaluated. RES has poor bioavailability, however, because it is metabolized quickly into glucuronide and sulfate conjugates, which are excreted through the urine [121]. However, present data suggest that RES is appropriate for cancer treatment and will be effective in combination with chemotherapy agents and targeted therapies.

RES has an anticancer effect on numerous cancer cells. However, the efficacy of this compound in animals is not promising, and results are inconsistent due to poor bioavailability in rodents and humans [122]. Studies suggest that many factors need to be considered, such as target the WNT [123] and silent information regulator (SIRT) signaling pathways [124], before being used for cancer therapy. RES modulates WNT signaling, which is activated in $>85 \%$ of colon cancers (NCT00256334). In a clinical study, a combination of RES (1000 mg twice a day) and myo-inositol (1000 mg twice a day) was effective for women diagnosed with polycystic ovary syndrome (NCT04867252). Generally, RES is effective for cancer prevention if taken orally as a supplement.

\subsection{Terpenes \\ Thymoquinone}

Thymoquinone (TQ), a terpene, is the active ingredient of the volatile oil of Nigella sativa, commonly known as black cumin or black seed [125]. TQ has anti-cancer characteristics that activate tumor suppressor genes such as PTEN and p21, reduce pro-inflammatory and angiogenic signals, and decrease DNA damage by inhibiting ROS formation [126-131]. Furthermore, by modulating the resistance mechanisms, TQ sensitizes cancer cells to the standard treatments of chemotherapy and radiotherapy [132]. The combination of TQ and cisplatin leads to better results than when used separately, with a higher apoptosis rate and $\mathrm{Bax} / \mathrm{Bcl}-2$ ratio [95]. These results indicate that TQ may be an agent for development as an OvCa drug.

\section{Nanocarriers as Vectors to Overcome MDR}

\subsection{Nanoparticles}

Nanotechnology applied to chemotherapeutic agents for cancer treatment can overcome drug resistance by inhibiting the function of various mechanisms, such as the efflux transporters on cell membranes. Nanoparticles provide a new way to deliver anti-cancer drugs by allowing direct access to the cells and providing a drug combination therapy platform [133]. The size, characteristics, and enhanced permeability and retention (EPR) effect for nanoparticle construction are the primary considerations [134]. For cancer therapy, nanoparticles with diameters of 10-100 $\mathrm{nm}$ achieve EPR and deliver drugs effectively. However, particles with sizes less than 1-2 $\mathrm{nm}$ can leak from the normal vasculature and damage normal cells. Particles larger than $100 \mathrm{~nm}$ can be cleared from circulation by phagocytes [134-136].

Moreover, surface modifications can impact the nanoparticle's half-life and its bioavailability. Therefore, nanoparticles are commonly altered to become hydrophilic, which increases drug circulation times and enhances penetration and accumulation in tumors [134,137-139]. For drug delivery by nanocarriers, targeting cancer cells is an essential characteristic, as it enhances the therapeutic efficiency of chemotherapeutic drugs and protects normal cells from cytotoxicity [134]. However, for a nanoparticle to deliver the chemotherapeutic agent, it must target the cells either passively or actively. A wide range of studies highlights that passive targeting of nanoparticles acts through the EPR effect that exploits the high vascular permeability and weak lymphatic drainage of cancer cells. The interaction between ligands and receptors achieves active targeting of nanoparticles. The receptors found on cancer cells include transferrin receptors, folate receptors, glycoproteins, and epidermal growth factor receptors [134]. Once the nanoparticle reaches the cancer cell and binds to a receptor, the drug is released to induce apoptosis. Nanoparticles are 
generally encapsulated with chemotherapeutic drugs or nucleic acids, implying that they can be involved in cytotoxicity and gene therapy [140]. In addition, nanoparticles can be used to encapsulate poorly soluble drugs and deliver them into circulation [141,142].

\subsection{Types of Nanoparticles}

The major types of nanoparticles used for cancer therapy and overcoming MDR include polymeric and solid lipid nanoparticles, liposomes, micelles, mesoporous silica nanoparticles, dendrimers, nanostructured lipid carriers, RNA interference structures, and planetary ball-milled (PBM) nanoparticles (Table 2).

Table 2. Nanocarrier drug therapeutics to treat OvCa.

\begin{tabular}{|c|c|c|c|}
\hline Nanoparticle Carrier & Therapeutic(s) & Results & Reference \\
\hline Polymeric nanoparticle & PTX + carboplatin & Increased potency in cells & [143] \\
\hline Solid lipid nanoparticle & PTX & Cytotoxicity and parenteral routes of administration & [144] \\
\hline Liposome & PTX & Increased expression of Akt, ERK, and caspase 3/9 & [145] \\
\hline Liposome & PTX + P-gp inhibitor & $\begin{array}{l}\text { High loading efficiency, high cytotoxicity, selective } \\
\text { targeting, and reversal of P-gp-mediated MDR }\end{array}$ & [146] \\
\hline Micelle & Fisetin & Increased cytotoxicity and inhibition of tumor growth & [147] \\
\hline $\begin{array}{l}\text { Mesoporous silica } \\
\text { nanoparticles }\end{array}$ & $\begin{array}{l}\text { Bcl-2 siRNA + } \\
\text { Doxorubicin }\end{array}$ & $\begin{array}{l}\text { Induced cell death, tumor suppression, and decreased cell } \\
\text { viability }\end{array}$ & [148] \\
\hline Telodendrimer & PTX + cisplatin & $\begin{array}{l}\text { High cytotoxicity and potent synergistic effect of } \\
\text { combined nanotherapy }\end{array}$ & [149] \\
\hline $\begin{array}{l}\text { RNA interference } \\
\text { therapy }\end{array}$ & $\begin{array}{c}\text { Hyaluronic acid } \\
\text { nanoparticles with } \\
\text { siRNA }\end{array}$ & Suppressed P-gp levels & [150] \\
\hline PBM nanoparticles & $\begin{array}{l}\text { RES + DTX + folic } \\
\text { acid }\end{array}$ & $\begin{array}{l}\text { Suppressed NF-kB p65 and reversal of the } \\
\text { ABC-transporter markers }\end{array}$ & [151] \\
\hline
\end{tabular}

\subsubsection{Polymeric and Solid Lipid Nanoparticles}

Polymeric nanoparticles (size: 3-200 nm), extensively used as drug carriers, are created by binding a copolymer to a polymer matrix. The nano-formulations include synthetic polymers such as poly(lactic-co-glycolic acid) and polycaprolactone (PCL) and natural polymers such as a polysaccharide or polypeptide [152,153]. The sizes of solid-lipid nanoparticles (SLNs) range from 50-1000 $\mathrm{nm}$. They are round, colloidal particles made up of lipids, chemotherapeutic drugs, and surfactants. Since spherical or round-shaped nanoparticles are favored for drug delivery, SLNs generally have better efficiency and capacity to overcome MDR by increasing drug uptake into cancer cells and inducing apoptosis [86]. Clinical tests have been conducted to assess chemotherapeutic drugs, including PTX, doxorubicin, camptothecin, and platinates as drug conjugates for various cancers. For instance, a combination of PTX and carboplatin polymeric nanoparticles was compared to the free drugs in targeting SKOV-3 and HO-8910 cells. Encapsulation of the drugs into nanoparticles increased their potency for OvCa cells [143]. Treatment with folic acid-PEGylated calix [4] arene nanoparticles reduced the tumor volumes of SKOV-3 xenografts compared with the free drugs. A study for identifying the role of PTXencapsulated SLNs [144] found similar cytotoxicity to commercial Cremophor EL-based PTX in MCF-7 (breast) and OVCAR-3 cells, suggesting that SLN-based nanoparticles are an effective delivery system for various routes of administration.

\subsubsection{Liposomes}

Liposomes (size: 50-200 nm) are spherical and contain one or multiple layered membrane structures. Liposomes are stable, biocompatible, biodegradable, non-toxic, and 
non-immunogenic, and they can accumulate in tumor cells by the EPR effect [154]. Strategies to augment drug bioavailability and efficiency for drug-resistant cancers include liposomes adapted for controlled release and ligand-targeted drug delivery into tumor cells [155]. Currently, PTX-, vincristine-, and camptothecin-encapsulated liposomes are in clinical tests. For example, Qi et al. (2018) [145] prepared PTX encapsulated in PEGylated liposomal nanoparticles (PL-PTX) to improve the efficiency in suppressing and killing OvCa cancer cells in vivo and in vitro. Furthermore, for OvCa cells, PL-PTX modulated the ERK/Akt pathway and induced apoptosis [145]. Additionally, co-encapsulation of a chemotherapeutic drug (doxorubicin) and a P-gp inhibitor (verapamil) into liposomes conjugated with transferrin showed better responses in terms of high loading efficiencies, selective targeting, high cytotoxicity, and reversal of drug resistance [86].

\subsubsection{Micelles}

Micelles (size: 10-100 nm) facilitate the penetrability and endocytosis of OvCa cells and impede the targeting of normal cells [156]. Micelles can also deliver water-insoluble chemotherapeutic drugs and inhibit drug resistance via the EPR effect, active internalization, endosomal-triggered release, and drug escape $[155,157]$. Moreover, micelles accumulate in poorly vascularized tumors, enhance EPR, and increase the half-lives of chemotherapeutic drugs [158]. To test this theory, Xiao et al. [147] investigated if fisetin micelles increase the inhibition of tumor cell growth. A xenograft model of SKOV-3 cells was established. After 21 days of treatment, fisetin micelle treatment led to $70.7 \%$ inhibition compared with free fisetin's $53.6 \%$. Thus, fisetin micelles are more powerful than free fisetin for inhibiting SKOV-3 cells [147].

\subsubsection{Mesoporous Silica Nanoparticles}

Surface modifications have been explored to facilitate drug loading capabilities. Mesoporous silica nanoparticles (MSNs) have high drug loading efficiency due to their high porous volume and surface area properties. In cancer cells, MSNs have multi-functionalities for targeted and controlled delivery, which allows for enhanced cellular uptake and the delivery of therapeutics at cellular levels [155]. Therefore, because of their advanced pharmacokinetics and treatment efficiency, MSNs are believed to be excellent vehicles for drug delivery [134]. This is a strategy used to treat cancer, mainly aiming to achieve a synergistic effect of a combined drug that can induce the death of tumor cells [159]. In this context, Choi et al. [148] used anti-apoptotic Bcl-2 gene-targeting siRNA (Bcl-2 siRNA) and $\mathrm{Ca}^{2+-}$ glued it onto bare MSNs, which were then co-loaded with the anti-cancer agent doxorubicin (DOX) to construct siRNA/DOX@Ca ${ }^{2+}$ MSNs. These MSNs were developed to evaluate the synergistic potential of an siRNA drug combination in SKOV-3 cells. These cells showed further compromised viability, showing that Bcl-2 silencing by co-delivered siRNA sensitized cancer cells to DOX-induced apoptosis. Furthermore, for mice, the therapeutic performance of co-delivered siRNA/DOX@Ca ${ }^{2+} \mathrm{MSNs}$ significantly increased tumor suppression more than DOX@MSNs and siRNA@Ca ${ }^{2+} \mathrm{MSNs}$, causing the transfected cancer cells to become sensitized to the apoptotic action of co-delivered DOX by Bcl-2 silencing [148].

\subsubsection{Dendrimers}

Dendrimers are 3D, hyper-branched, and globular nanoparticles. They can be engineered with sizes of 1-15 $\mathrm{nm}$. These nanoparticles have distinctive features, including a low polydispersity index and high-water solubility, biocompatibility, polyvalency, and molecular weights. They can be used to encapsulate both hydrophilic and hydrophobic drugs [86,160]. For the treatment of OvCa cells, Cai et al. (2015) [149] designed a linear-dendritic telodendrimer micelle (TM) nanocarrier to analyze the synergistic effects of delivering two chemotherapeutic agents, cisplatin and PTX, which are hydrophilic and hydrophobic drugs, respectively. The encapsulation of both agents exhibited higher cytotoxicity toward SKOV-3 OvCa cells, demonstrating a synergistic effect. There was 
greater cytotoxicity for the combination of a 2:1 ratio of cisplatin and PTX in the co-loading formulation at 50\% cell killing compared with other treatments (PTX, cisplatin, TM (PTX), and TM (cisplatin)), indicating a synergistic effect on resistant SKOV-3 cells [149]. Overall, since dendrimers are extraordinary drug delivery nanocarriers, research endeavors have been dedicated to evading cytotoxicity and promoting translation into clinical uses [161].

\subsubsection{RNA Interference Therapy}

Since gene silencing by RNA interference (RNAi) was discovered, many studies have included small interfering RNAs (siRNAs), short hairpin RNAs, or antisense oligodeoxynucleotides as therapeutic options to treat cancer [162]. The constructed siRNA-targeted MDR genes can silence P-gP or MDR1, MRP1, Bcl2, and BCRP and overcome drug resistance. However, to date, the therapeutic efficiency of these RNA interference strategies has not been consistently satisfactory [86]. Therefore, the idea of encapsulating siRNAs into nanoparticles can be effective due to their capacity to avoid rapid degradation of siRNA molecules, its limited exposure to normal cells, its increased cellular targeting, and increased uptake [163]. Yang et al. [150] focused on the MDR gene product P-gp. The encapsulated ABCB1 siRNA hyaluronic acid (HA) nanoparticles targeted cancer cells overexpressing surface protein CD44 [150]. An in vitro study was conducted to determine whether the delivered MDR1 siRNA was released from the nanoparticles and retained its functional activity of knocking down the expression of MDR1. For OVCAR8TR PTXresistant OvCa cells, HA nanoparticle delivery downregulated the P-gp levels, indicating that HA nanoparticles could be used as a therapeutic to re-sensitize cells to PTX [164]. However, to support the biological significance of the in vitro findings and evaluate the antitumor efficacy of HA-PEI/HAPEG/MDR1 siRNA nanoparticles in mice, OVAR8TR were grown as xenografts in nude mice. The results revealed that treatment with HAPEI/HA-PEG/MDR1 siRNA nanoparticles followed by PTX treatment produced a significant inhibitory effect on the growth of resistant tumors compared with the control groups [150]. Co-delivery of siRNA and chemotherapeutic drugs improves the efficiency of chemotherapy by inducing apoptosis and preventing the expression of anti-apoptotic proteins such as Bcl-2 or survivin [165-168].

\subsubsection{Planetary Ball-Milled Nanoparticles}

Although other types of nanoparticles are used for drug delivery and targeted therapies, in recent years, planetary ball-milled (PBM) nanoparticles (NPs) have been reported as being more innovative than others. The major issues for the other drug delivery methods are poor aqueous solubility, bioavailability, and absorption [169]. However, PBM nanoparticles are innovative since they are scalable and easy to produce. They have a starch inner core coated with biodegradable copolymers (PCL and polyethylene glycol (PCL-PEG)) milled into a spherical shape and a uniform particle size. Furthermore, Singh et al. (2018) [151] reported that PBM-NPs have 100\% loading efficiency for drugs, whether hydrophobic or hydrophilic, and have a control surface logP (metric for hydrophobic and hydrophilic distribution) for systemic, oral, or cutaneous delivery. In PBM techniques, heatabsorbent zirconium oxide planetary milling balls and jars are used to mill the particles that rotate around a shared axis of the chamber wheel. In general, for efficient delivery to the target tumor cells, a round shape and a size $<100 \mathrm{~nm}$ for the NPs are more favorable [170]. By controlling the size and number of zirconium oxide balls, milling cycles, grinding speed, centrifugal force, and planetary jar velocity, PBM can engineer the NP size range from $5 \mathrm{~nm}$ to $60 \mu \mathrm{m}[151,169,171]$ (Figure 2). Surface polymers can be modified during PBM nano-formulations to deliver encapsulated agents by conjugating targeting molecules such as antibodies, folate, and nucleic acid aptamers [120,171,172] For folate receptor-based targeted therapy, Singh et al. (2018) [151] fabricated PBM-NPs with folic acid on the surface. They encapsulated it with the natural compound RES and docetaxel (DTX) to treat prostate cancer cells. In this study, PBM-NPs coated by folic acid suppressed NF-kB p65, which is involved in inflammation and promotes apoptosis. Furthermore, they showed that 
PBM-NPs reverse the ABC transporter markers in DTX-resistant PCa cells, limiting the MDR phenotype of the cancer cells. Recent studies also showed that PBM-NPs can target hedgehog signaling pathways in DTX-resistant cells and reverse MDR [148]. Altogether, PBM-NPs have a high potential to encapsulate drugs and are safer and more efficient in the selective targeting of cancer cells. If applied to OvCa cells, they may provide effective therapy for cancers with chemoresistance.
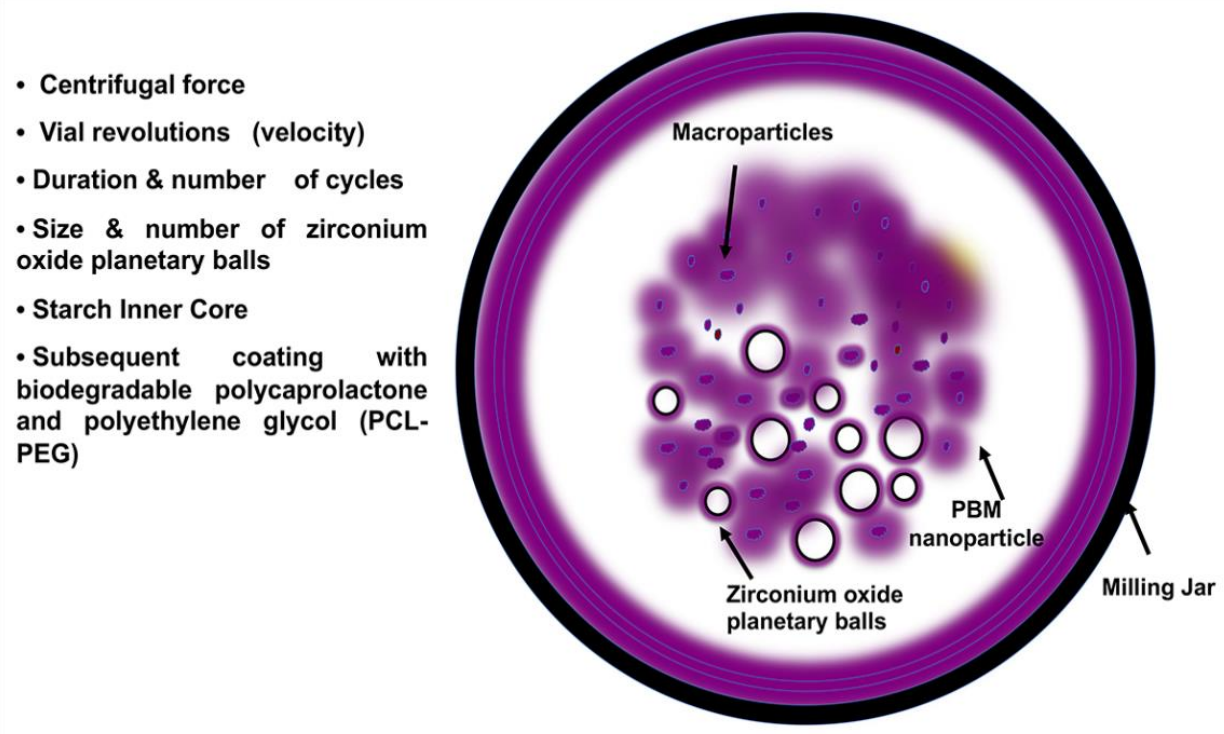

Figure 2. PBM nanoparticle formulation. PBM requires a milling jar, which holds various sizes of heat-absorbent zirconium oxide planetary milling balls. By controlling the size and number of balls, milling cycles, grinding speed, centrifugal force, and planetary jar velocity, PBM can engineer NP size ranges from $5 \mathrm{~nm}$ to $60 \mu \mathrm{m}$. The arrows indicate the milling jar, PBM nanoparticles containing starch inner cores and encapsulated drugs, zirconium oxide balls, and the macroparticles.

\section{Conclusions}

For cancer therapy, drug resistance has been an enduring problem. Standard cancer treatments frequently lead to MDR and often do not produce cures. However, new strategies can take cancer therapy to higher levels. We have reviewed some of these new strategies, including CAR-T cell therapy, PARPi therapy, natural products, nanoparticles, and RNA interference therapy.

Plants remain a promising pool of drug discovery scaffolds. Natural compounds have various targets, including MDR in cancer cells, have high specificity, are safer, and allow for treatment that has anti-cancer potential with low toxicity. However, rapid metabolism, low bioavailability, and inadequate drug delivery are limiting factors. To overcome these challenges, delivering these compounds in nanocarriers will improve their translation. Nanoparticles and RNA interference therapies allow for targeted and rational treatments with impressive effects. In this context, we [151] have developed PBM engineering technology which allows for the nanoparticle-based drug delivery of hydrophilic and hydrophobic drugs with high loading efficiency, which was previously considered inaccessible. Thus, the idea of combining natural products with chemotherapeutics and encapsulating them in nanocarriers presents a new therapeutic strategy for overcoming drug resistance in cancer cells.

Author Contributions: M.M. and S.K.S. wrote the original draft of the manuscript; G.O.-I. reviewed and edited the manuscript; R.S. conceptualized and critically reviewed and edited the manuscript. All authors have read and agreed to the published version of the manuscript.

Funding: This work was supported by the National Institutes of Health (Award Numbers SC1CA193758; U54CA118638) and the Department of Defense (Award Number W81XWH1810429). 
Acknowledgments: We express our gratitude to Donald L. Hill for editing and proofreading the manuscript.

Conflicts of Interest: The authors declare that they have no competing interest.

\section{References}

1. American Cancer Society. Ovarian Cancer Statistics: How Common Is Ovarian Cancer; American Cancer Society: Atlanta, GA, USA, 2021.

2. Siegel, R.L.; Miller, K.D.; Fuchs, H.E.; Jemal, A. Cancer statistics, 2021. CA Cancer J. Clin. 2021, 71, 7-33. [CrossRef] [PubMed]

3. Singh, S.K.; Apata, T.; Singh, S.; McFadden, M.; Singh, R. Clinical implication of metformin in relation to diabetes mellitus and ovarian cancer. Biomedicines 2021, 9, 1020. [CrossRef]

4. Schumer, S.T.; Cannistra, S.A. Granulosa cell tumor of the ovary. J. Clin. Oncol. 2003, 21, 1180-1189. [CrossRef]

5. Raja, F.A.; Chopra, N.; Ledermann, J.A. Optimal first-line treatment in ovarian cancer. Ann. Oncol. 2012, 23 (Suppl. S10), 118-127. [CrossRef]

6. Chandra, A.; Pius, C.; Nabeel, M.; Nair, M.; Vishwanatha, J.K.; Ahmad, S.; Basha, R. Ovarian cancer: Current status and strategies for improving therapeutic outcomes. Cancer Med. 2019, 8, 7018-7031. [CrossRef] [PubMed]

7. National Cancer Institute. SEER Cancer Statistics Review; National Cancer Institute: Bethesda, MD, USA, 2016.

8. Ukwade, C.E.; Ebuehi, O.A.T.; Adisa, R.A.; Singh, S.K.; Singh, R. Anti-proliferative activities of Byrsocarpus coccineus Schum. and Thonn. (Connaraceae) using ovarian cancer cell lines. J. Ovarian Res. 2020, 13, 83. [CrossRef] [PubMed]

9. Mansoori, B.; Mohammadi, A.; Davudian, S.; Shirjang, S.; Baradaran, B. The different mechanisms of cancer drug resistance: A brief review. Adv. Pharm. Bull. 2017, 7, 339-348. [CrossRef] [PubMed]

10. Montanari, F.; Ecker, G.F. Prediction of drug-ABC-transporter interaction-Recent advances and future challenges. Adv. Drug Deliv. Rev. 2015, 86, 17-26. [CrossRef]

11. Lawlor, D.; Martin, P.; Busschots, S.; Thery, J.; O’Leary, J.J.; Hennessy, B.T.; Stordal, B. PARP Inhibitors as P-glyoprotein Substrates. J. Pharm. Sci. 2014, 103, 1913-1920. [CrossRef]

12. Santos, S.A.; Paulo, A. Small molecule inhibitors of multidrug resistance gene (MDR1) expression: Preclinical evaluation and mechanisms of action. Curr. Cancer Drug Targets 2013, 13, 814-828. [CrossRef]

13. Szakács, G.; Paterson, J.K.; Ludwig, J.A.; Booth-Genthe, C.; Gottesman, M.M. Targeting multidrug resistance in cancer. Nat. Rev. Drug Discov. 2006, 5, 219-234. [CrossRef]

14. Patch, A.M.; Christie, E.L.; Etemadmoghadam, D.; Garsed, D.W.; George, J.; Fereday, S.; Nones, K.; Cowin, P.; Alsop, K.; Bailey, P.J.; et al. Whole-genome characterization of chemoresistant ovarian cancer. Nature 2015, 521, 489-494. [CrossRef] [PubMed]

15. Kenicer, J.; Spears, M.; Lyttle, N.; Taylor, K.J.; Liao, L.; Cunningham, C.A.; Lambros, M.; MacKay, A.; Yao, C.; Reis-Filho, J.; et al. Molecular characterisation of isogenic taxane resistant cell lines identify novel drivers of drug resistance. BMC Cancer 2014, 14, 762. [CrossRef] [PubMed]

16. Nishio, S.; Ushijima, K. Clinical significance of primary debulking surgery and neoadjuvant chemotherapy-interval debulking surgery in advanced ovarian cancer. Jpn. J. Clin. Oncol. 2020, 50, 379-386. [CrossRef] [PubMed]

17. Prat, J. Staging classification for cancer of the ovary, fallopian tube, and peritoneum. Int. J. Gynaecol. Obstet. 2014, 124, 1-5. [CrossRef]

18. Kim, S.; Han, Y.; Kim, S.I.; Kim, H.-S.; Kim, S.J.; Song, Y.S. Tumor evolution and chemoresistance in ovarian cancer. NPJ Precis. Oncol. 2018, 2, 20. [CrossRef]

19. Heintz, A.P.; Odicino, F.; Maisonneuve, P.; Quinn, M.A.; Benedet, J.L.; Creasman, W.T.; Ngan, H.Y.; Pecorelli, S.; Beller, U. Carcinoma of the ovary. FIGO 26th Annual Report on the Results of Treatment in Gynecological Cancer. Int. J. Gynaecol. Obstet. 2006, 95 (Suppl. S1), S161-S192. [CrossRef]

20. Salani, R.; Axtell, A.; Gerardi, M.; Holschneider, C.; Bristow, R.E. Limited utility of conventional criteria for predicting unresectable disease in patients with advanced stage epithelial ovarian cancer. Gynecol. Oncol. 2008, 108, 271-275. [CrossRef]

21. Schorge, J.O.; McCann, C.; Del Carmen, M.G. Surgical debulking of ovarian cancer: What difference does it make? Rev. Obstet. Gynecol. 2010, 3, 111-117.

22. Du Bois, A.; Reuss, A.; Pujade-Lauraine, E.; Harter, P.; Ray-Coquard, I.; Pfisterer, J. Role of surgical outcome as prognostic factor in advanced epithelial ovarian cancer: A combined exploratory analysis of 3 prospectively randomized phase 3 multicenter trials: By the Arbeitsgemeinschaft Gynaekologische Onkologie Studiengruppe Ovarialkarzinom (AGO-OVAR) and the Groupe d'Investigateurs Nationaux Pour les Etudes des Cancers de l'Ovaire (GINECO). Cancer 2009, 115, 1234-1244. [CrossRef]

23. Hacker, N.F. State of the art of surgery in advanced epithelial ovarian cancer. Ann. Oncol. 2013, 24 (Suppl. S10), 27-32. [CrossRef]

24. Wright, J.D.; Ananth, C.V.; Tsui, J.; Glied, S.A.; Burke, W.M.; Lu, Y.S.; Neugut, A.I.; Herzog, T.J.; Hershman, D.L. Comparative effectiveness of upfront treatment strategies in elderly women with ovarian cancer. Cancer 2014, 120, 1246-1254. [CrossRef] [PubMed]

25. Brockbank, E.C.; Ind, T.E.; Barton, D.P.; Shepherd, J.H.; Gore, M.E.; A'Hern, R.; Bridges, J.E. Preoperative predictors of suboptimal primary surgical cytoreduction in women with clinical evidence of advanced primary epithelial ovarian cancer. Int. J. Gynecol. Cancer 2004, 14, 42-50. [CrossRef] [PubMed] 
26. Vergote, I.; Tropé, C.G.; Amant, F.; Kristensen, G.B.; Ehlen, T.; Johnson, N.; Verheijen, R.H.; van der Burg, M.E.; Lacave, A.J.; Panici, P.B.; et al. Neoadjuvant chemotherapy or primary surgery in stage IIIC or IV ovarian cancer. N. Engl. J. Med. 2010, 363, 943-953. [CrossRef] [PubMed]

27. Rutten, I.J.; van de Laar, R.; Kruitwagen, R.F.; Bakers, F.C.; Ploegmakers, M.J.; Pappot, T.W.; Beets-Tan, R.G.; Massuger, L.F.; Zusterzeel, P.L.; Van Gorp, T. Prediction of incomplete primary debulking surgery in patients with advanced ovarian cancer: An external validation study of three models using computed tomography. Gynecol. Oncol. 2016, 140, 22-28. [CrossRef]

28. Basta, A.B.M.; Bieńkiewicz, A.; Blecharz, P.; Bodnar, L.; Jach, R.; Knapp, P.; Kojs, Z.; Kotarski, J.; Markowska, J.; Misiek, M.; et al. Recommendation of the Polish society of oncological gynaecology on the diagnosis and treatment of epithelial ovarian cancer. Oncol. Clin. Pract. 2015, 11, 11.

29. Parmar, M.K.; Ledermann, J.A.; Colombo, N.; du Bois, A.; Delaloye, J.F.; Kristensen, G.B.; Wheeler, S.; Swart, A.M.; Qian, W.; Torri, V.; et al. Paclitaxel plus platinum-based chemotherapy versus conventional platinum-based chemotherapy in women with relapsed ovarian cancer: The ICON4/AGO-OVAR-2.2 trial. Lancet 2003, 361, 2099-2106. [CrossRef]

30. Ozaki, S.; Takigawa, N.; Ichihara, E.; Hotta, K.; Oze, I.; Kurimoto, E.; Fushimi, S.; Ogino, T.; Tabata, M.; Tanimoto, M.; et al. Favorable response of heavily treated Wilms' tumor to paclitaxel and carboplatin. Onkologie 2012, 35, 283-286. [CrossRef]

31. Cristea, M.; Han, E.; Salmon, L.; Morgan, R.J. Practical considerations in ovarian cancer chemotherapy. Ther. Adv. Med. Oncol. 2010, 2, 175-187. [CrossRef]

32. Högberg, T.; Glimelius, B.; Nygren, P. A systematic overview of chemotherapy effects in ovarian cancer. Acta Oncol. 2001, 40, 340-360. [CrossRef]

33. Aabo, K.; Adams, M.; Adnitt, P.; Alberts, D.S.; Athanazziou, A.; Barley, V.; Bell, D.R.; Bianchi, U.; Bolis, G.; Brady, M.F.; et al. Chemotherapy in advanced ovarian cancer: Four systematic meta-analyses of individual patient data from 37 randomized trials. Advanced Ovarian Cancer Trialists' Group. Br. J. Cancer 1998, 78, 1479-1487. [CrossRef] [PubMed]

34. Neijt, J.P.; Engelholm, S.A.; Tuxen, M.K.; Sorensen, P.G.; Hansen, M.; Sessa, C.; de Swart, C.A.; Hirsch, F.R.; Lund, B.; van Houwelingen, H.C. Exploratory phase III study of paclitaxel and cisplatin versus paclitaxel and carboplatin in advanced ovarian cancer. J. Clin. Oncol. 2000, 18, 3084-3092. [CrossRef]

35. Pokhriyal, R.; Hariprasad, R.; Kumar, L.; Hariprasad, G. Chemotherapy resistance in advanced ovarian cancer patients. Biomark Cancer 2019, 11, 1179299X19860815. [CrossRef] [PubMed]

36. Damia, G.; Broggini, M. Platinum Resistance in Ovarian Cancer: Role of DNA Repair. Cancers 2019, 11, 119. [CrossRef] [PubMed]

37. Davis, A.; Tinker, A.V.; Friedlander, M. "Platinum resistant" ovarian cancer: What is it, who to treat and how to measure benefit? Gynecol. Oncol. 2014, 133, 624-631. [CrossRef] [PubMed]

38. Einzig, A.I.; Wiernik, P.H.; Sasloff, J.; Runowicz, C.D.; Goldberg, G.L. Phase II study and long-term follow-up of patients treated with taxol for advanced ovarian adenocarcinoma. J. Clin. Oncol. 1992, 10, 1748-1753. [CrossRef] [PubMed]

39. McGrogan, B.T.; Gilmartin, B.; Carney, D.N.; McCann, A. Taxanes, microtubules and chemoresistant breast cancer. Biochim. Biophys. Acta 2008, 1785, 96-132. [CrossRef]

40. Schnerch, D.; Follo, M.; Krohs, J.; Felthaus, J.; Engelhardt, M.; Wäsch, R. Monitoring APC/C activity in the presence of chromosomal misalignment in unperturbed cell populations. Cell Cycle 2012, 11, 310-321. [CrossRef]

41. González-Martín, A.; Pothuri, B.; Vergote, I.; DePont Christensen, R.; Graybill, W.; Mirza, M.R.; McCormick, C.; Lorusso, D.; Hoskins, P.; Freyer, G.; et al. Niraparib in patients with newly diagnosed advanced ovarian cancer. N. Engl. J. Med. 2019, 381, 2391-2402. [CrossRef]

42. Montemorano, L.; Lightfoot, M.D.; Bixel, K. Role of olaparib as maintenance treatment for ovarian cancer: The evidence to date. OncoTargets Ther. 2019, 12, 11497-11506. [CrossRef]

43. Lord, C.J.; Ashworth, A. PARP inhibitors: Synthetic lethality in the clinic. Science 2017, 355, 1152-1158. [CrossRef] [PubMed]

44. Dedes, K.J.; Wetterskog, D.; Mendes-Pereira, A.M.; Natrajan, R.; Lambros, M.B.; Geyer, F.C.; Vatcheva, R.; Savage, K.; Mackay, A.; Lord, C.J.; et al. PTEN deficiency in endometrioid endometrial adenocarcinomas predicts sensitivity to PARP inhibitors. Sci. Transl. Med. 2010, 2, 53ra75. [CrossRef] [PubMed]

45. Shen, W.H.; Balajee, A.S.; Wang, J.; Wu, H.; Eng, C.; Pandolfi, P.P.; Yin, Y. Essential role for nuclear PTEN in maintaining chromosomal integrity. Cell 2007, 128, 157-170. [CrossRef]

46. Li, H.; Liu, Z.Y.; Wu, N.; Chen, Y.C.; Cheng, Q.; Wang, J. PARP inhibitor resistance: The underlying mechanisms and clinical implications. Mol. Cancer 2020, 19, 107. [CrossRef]

47. Kim, A.; Ueda, Y.; Naka, T.; Enomoto, T. Therapeutic strategies in epithelial ovarian cancer. J. Exp. Clin. Cancer Res. 2012, 31, 14. [CrossRef]

48. Zhu, X.; Cai, H.; Zhao, L.; Ning, L.; Lang, J. CAR-T cell therapy in ovarian cancer: From the bench to the bedside. Oncotarget 2017, 8, 64607-64621. [CrossRef]

49. June, C.H.; O'Connor, R.S.; Kawalekar, O.U.; Ghassemi, S.; Milone, M.C. CAR T cell immunotherapy for human cancer. Science 2018, 359, 1361-1365. [CrossRef]

50. Aoki, Y.; Takakuwa, K.; Kodama, S.; Tanaka, K.; Takahashi, M.; Tokunaga, A.; Takahashi, T. Use of adoptive transfer of tumorinfiltrating lymphocytes alone or in combination with cisplatin-containing chemotherapy in patients with epithelial ovarian cancer. Cancer Res. 1991, 51, 1934-1939.

51. Porter, D.L.; Levine, B.L.; Kalos, M.; Bagg, A.; June, C.H. Chimeric antigen receptor-modified T cells in chronic lymphoid leukemia. N. Engl. J. Med. 2011, 365, 725-733. [CrossRef] 
52. Brentjens, R.J.; Rivière, I.; Park, J.H.; Davila, M.L.; Wang, X.; Stefanski, J.; Taylor, C.; Yeh, R.; Bartido, S.; Borquez-Ojeda, O.; et al. Safety and persistence of adoptively transferred autologous CD19-targeted T cells in patients with relapsed or chemotherapy refractory B-cell leukemias. Blood 2011, 118, 4817-4828. [CrossRef] [PubMed]

53. Zhang, H.; Ye, Z.L.; Yuan, Z.G.; Luo, Z.Q.; Jin, H.J.; Qian, Q.J. New strategies for the treatment of solid tumors with CAR-T cells. Int. J. Biol. Sci. 2016, 12, 718-729. [CrossRef]

54. Slaney, C.Y.; Kershaw, M.H.; Darcy, P.K. Trafficking of T cells into tumors. Cancer Res. 2014, 74, 7168-7174. [CrossRef]

55. Park, H.J.; Kusnadi, A.; Lee, E.J.; Kim, W.W.; Cho, B.C.; Lee, I.J.; Seong, J.; Ha, S.J. Tumor-infiltrating regulatory T cells delineated by upregulation of PD-1 and inhibitory receptors. Cell. Immunol. 2012, 278, 76-83. [CrossRef] [PubMed]

56. Wu, J.W.Y.; Dand, S.; Doig, L.; Papenfuss, A.T.; Scott, C.L.; Ho, G.; Ooi, J.D. T-cell receptor therapy in the treatment of ovarian cancer: A mini review. Front. Immunol. 2021, 12, 672502. [CrossRef] [PubMed]

57. Zhang, J.; Wang, L. The emerging world of TCR-T cell trials against cancer: A systematic review. Technol. Cancer Res. Treat. 2019, 18, 1533033819831068. [CrossRef] [PubMed]

58. Mehta, K.; Fok, J. Targeting transglutaminase-2 to overcome chemoresistance in cancer cells. In Drug Resistance in Cancer Cells; Springer: New York, NY, USA, 2009; pp. 95-114. [CrossRef]

59. Housman, G.; Byler, S.; Heerboth, S.; Lapinska, K.; Longacre, M.; Snyder, N.; Sarkar, S. Drug resistance in cancer: An overview. Cancers 2014, 6, 1769-1792. [CrossRef]

60. Zhang, Y.; Cao, L.; Nguyen, D.; Lu, H. TP53 mutations in epithelial ovarian cancer. Transl. Cancer Res. 2016, 5, 650-663. [CrossRef]

61. Rivlin, N.; Brosh, R.; Oren, M.; Rotter, V. Mutations in the p53 tumor suppressor gene: Important milestones at the various steps of tumorigenesis. Genes Cancer 2011, 2, 466-474. [CrossRef]

62. Bush, J.A.; Li, G. Cancer chemoresistance: The relationship between p53 and multidrug transporters. Int. J. Cancer 2002, 98, 323-330. [CrossRef]

63. Aas, T.; Børresen, A.L.; Geisler, S.; Smith-Sørensen, B.; Johnsen, H.; Varhaug, J.E.; Akslen, L.A.; Lønning, P.E. Specific P53 mutations are associated with de novo resistance to doxorubicin in breast cancer patients. Nat. Med. 1996, 2, 811-814. [CrossRef]

64. Abal, M.; Andreu, J.M.; Barasoain, I. Taxanes: Microtubule and centrosome targets, and cell cycle dependent mechanisms of action. Curr. Cancer Drug Targets 2003, 3, 193-203. [CrossRef] [PubMed]

65. Jordan, M.A.; Wilson, L. Microtubules as a target for anticancer drugs. Nat. Rev. Cancer 2004, 4, 253-265. [CrossRef]

66. Gonzalez-Garay, M.L.; Chang, L.; Blade, K.; Menick, D.R.; Cabral, F. A beta-tubulin leucine cluster involved in microtubule assembly and paclitaxel resistance. J. Biol. Chem. 1999, 274, 23875-23882. [CrossRef]

67. Berrieman, H.K.; Lind, M.J.; Cawkwell, L. Do beta-tubulin mutations have a role in resistance to chemotherapy? Lancet. Oncol. 2004, 5, 158-164. [CrossRef]

68. Kavallaris, M.; Tait, A.S.; Walsh, B.J.; He, L.; Horwitz, S.B.; Norris, M.D.; Haber, M. Multiple microtubule alterations are associated with Vinca alkaloid resistance in human leukemia cells. Cancer Res. 2001, 61, 5803-5809. [PubMed]

69. Hua, X.H.; Genini, D.; Gussio, R.; Tawatao, R.; Shih, H.; Kipps, T.J.; Carson, D.A.; Leoni, L.M. Biochemical genetic analysis of indanocine resistance in human leukemia. Cancer Res. 2001, 61, 7248-7254. [PubMed]

70. Hari, M.; Loganzo, F.; Annable, T.; Tan, X.; Musto, S.; Morilla, D.B.; Nettles, J.H.; Snyder, J.P.; Greenberger, L.M. Paclitaxel-resistant cells have a mutation in the paclitaxel-binding region of beta-tubulin (Asp26Glu) and less stable microtubules. Mol. Cancer Ther. 2006, 5, 270-278. [CrossRef] [PubMed]

71. Martello, L.A.; Verdier-Pinard, P.; Shen, H.J.; He, L.; Torres, K.; Orr, G.A.; Horwitz, S.B. Elevated levels of microtubule destabilizing factors in a Taxol-resistant/dependent A549 cell line with an alpha-tubulin mutation. Cancer Res. 2003, 63, 1207-1213. [PubMed]

72. Dieras, V.; Vincent-Salomon, A.; Degeorges, A.; Beuzeboc, P.; Mignot, L.; de Cremoux, P. Trastuzumab (Herceptin) and breast cancer: Mechanisms of resistance. Bull. Cancer 2007, 94, 259-266.

73. Berns, K.; Horlings, H.M.; Hennessy, B.T.; Madiredjo, M.; Hijmans, E.M.; Beelen, K.; Linn, S.C.; Gonzalez-Angulo, A.M.; StemkeHale, K.; Hauptmann, M.; et al. A functional genetic approach identifies the PI3K pathway as a major determinant of trastuzumab resistance in breast cancer. Cancer Cell 2007, 12, 395-402. [CrossRef] [PubMed]

74. Fresno Vara, J.A.; Casado, E.; de Castro, J.; Cejas, P.; Belda-Iniesta, C.; González-Barón, M. PI3K/Akt signalling pathway and cancer. Cancer Treat. Rev. 2004, 30, 193-204. [CrossRef] [PubMed]

75. Chang, F.; Lee, J.T.; Navolanic, P.M.; Steelman, L.S.; Shelton, J.G.; Blalock, W.L.; Franklin, R.A.; McCubrey, J.A. Involvement of PI3K/Akt pathway in cell cycle progression, apoptosis, and neoplastic transformation: A target for cancer chemotherapy. Leukemia 2003, 17, 590-603. [CrossRef] [PubMed]

76. Cheng, J.Q.; Lindsley, C.W.; Cheng, G.Z.; Yang, H.; Nicosia, S.V. The Akt/PKB pathway: Molecular target for cancer drug discovery. Oncogene 2005, 24, 7482-7492. [CrossRef]

77. Borst, P.; Evers, R.; Kool, M.; Wijnholds, J. A family of drug transporters: The multidrug resistance-associated proteins. J. Natl. Cancer Inst. 2000, 92, 1295-1302. [CrossRef] [PubMed]

78. Zahreddine, H.; Borden, K.L. Mechanisms and insights into drug resistance in cancer. Front. Pharmacol. 2013, 4, 28. [CrossRef]

79. Gottesman, M.M. Mechanisms of cancer drug resistance. Annu. Rev. Med. 2002, 53, 615-627. [CrossRef] [PubMed]

80. Townsend, D.M.; Tew, K.D. The role of glutathione-S-transferase in anti-cancer drug resistance. Oncogene 2003, 22, 7369-7375. [CrossRef] [PubMed] 
81. Sauna, Z.E.; Ambudkar, S.V. Characterization of the catalytic cycle of ATP hydrolysis by human P-glycoprotein. The two ATP hydrolysis events in a single catalytic cycle are kinetically similar but affect different functional outcomes. J. Biol. Chem. 2001, 276, 11653-11661. [CrossRef]

82. Hopper-Borge, E.; Chen, Z.S.; Shchaveleva, I.; Belinsky, M.G.; Kruh, G.D. Analysis of the drug resistance profile of multidrug resistance protein 7 (ABCC10): Resistance to docetaxel. Cancer Res. 2004, 64, 4927-4930. [CrossRef]

83. Maliepaard, M.; van Gastelen, M.A.; de Jong, L.A.; Pluim, D.; van Waardenburg, R.C.; Ruevekamp-Helmers, M.C.; Floot, B.G.; Schellens, J.H. Overexpression of the BCRP/MXR/ABCP gene in a topotecan-selected ovarian tumor cell line. Cancer Res. 1999, $59,4559-4563$.

84. Fontana, F.; Carollo, E.; Melling, G.E.; Carter, D.R.F. Extracellular vesicles: Emerging modulators of cancer drug resistance. Cancers 2021, 13, 749. [CrossRef] [PubMed]

85. Au Yeung, C.L.; Co, N.N.; Tsuruga, T.; Yeung, T.L.; Kwan, S.Y.; Leung, C.S.; Li, Y.; Lu, E.S.; Kwan, K.; Wong, K.K.; et al. Exosomal transfer of stroma-derived miR21 confers paclitaxel resistance in ovarian cancer cells through targeting APAF1. Nat. Commun. 2016, 7, 11150. [CrossRef] [PubMed]

86. Majidinia, M.; Mirza-Aghazadeh-Attari, M.; Rahimi, M.; Mihanfar, A.; Karimian, A.; Safa, A.; Yousefi, B. Overcoming multidrug resistance in cancer: Recent progress in nanotechnology and new horizons. IUBMB Life 2020, 72, 855-871. [CrossRef]

87. Duvshani-Eshet, M.; Benny, O.; Morgenstern, A.; Machluf, M. Therapeutic ultrasound facilitates antiangiogenic gene delivery and inhibits prostate tumor growth. Mol. Cancer Ther. 2007, 6, 2371-2382. [CrossRef]

88. Deng, Z.; Yan, F.; Jin, Q.; Li, F.; Wu, J.; Liu, X.; Zheng, H. Reversal of multidrug resistance phenotype in human breast cancer cells using doxorubicin-liposome-microbubble complexes assisted by ultrasound. J. Controll. Release 2014, 174, 109-116. [CrossRef] [PubMed]

89. Bisi, A.; Cappadone, C.; Rampa, A.; Farruggia, G.; Sargenti, A.; Belluti, F.; Di Martino, R.M.C.; Malucelli, E.; Meluzzi, A.; Iotti, S.; et al. Coumarin derivatives as potential antitumor agents: Growth inhibition, apoptosis induction and multidrug resistance reverting activity. Eur. J. Med. Chem. 2017, 127, 577-585. [CrossRef]

90. Mignani, S.; Rodrigues, J.; Tomas, H.; Zablocka, M.; Shi, X.; Caminade, A.M.; Majoral, J.P. Dendrimers in combination with natural products and analogues as anti-cancer agents. Chem. Soc. Rev. 2018, 47, 514-532. [CrossRef]

91. Qiu, M.; Xue, C.; Zhang, L. Piperine alkaloid induces anticancer and apoptotic effects in cisplatin resistant ovarian carcinoma by inducing G2/M phase cell cycle arrest, caspase activation and inhibition of cell migration and PI3K/Akt/GSK3 $\beta$ signalling pathway. Off. J. Balkan Union Oncol. 2019, 24, 2316-2321.

92. Teekaraman, D.; Elayapillai, S.P.; Viswanathan, M.P.; Jagadeesan, A. Quercetin inhibits human metastatic ovarian cancer cell growth and modulates components of the intrinsic apoptotic pathway in PA-1 cell line. Chem. -Biol. Interact. 2019, 300, 91-100. [CrossRef] [PubMed]

93. Pourhanifeh, M.H.; Darvish, M.; Tabatabaeian, J.; Fard, M.R.; Mottaghi, R.; Azadchehr, M.J.; Jahanshahi, M.; Sahebkar, A.; Mirzaei, $\mathrm{H}$. Therapeutic role of curcumin and its novel formulations in gynecological cancers. J. Ovarian Res. 2020, 13, 130. [CrossRef] [PubMed]

94. Lang, F.; Qin, Z.; Li, F.; Zhang, H.; Fang, Z.; Hao, E. Apoptotic cell death induced by resveratrol is partially mediated by the autophagy pathway in human ovarian cancer cells. PLoS ONE 2015, 10, e0129196. [CrossRef] [PubMed]

95. Liu, X.; Dong, J.; Cai, W.; Pan, Y.; Li, R.; Li, B. The effect of thymoquinone on apoptosis of SK-OV-3 ovarian cancer cell by regulation of Bcl-2 and bax. Int. J. Gynecol. Cancer 2017, 27, 1596. [CrossRef] [PubMed]

96. Anwanwan, D.; Singh, S.K.; Singh, S.; Saikam, V.; Singh, R. Challenges in liver cancer and possible treatment approaches. Biochim. Biophys. Acta Rev. Cancer 2020, 1873, 188314. [CrossRef] [PubMed]

97. Stevenson, W.S.; Best, O.G.; Przybylla, A.; Chen, Q.; Singh, N.; Koleth, M.; Pierce, S.; Kennedy, T.; Tong, W.; Kuang, S.Q.; et al. DNA methylation of membrane-bound tyrosine phosphatase genes in acute lymphoblastic leukaemia. Leukemia 2014, 28, 787-793. [CrossRef] [PubMed]

98. Do, M.T.; Kim, H.G.; Choi, J.H.; Khanal, T.; Park, B.H.; Tran, T.P.; Jeong, T.C.; Jeong, H.G. Antitumor efficacy of piperine in the treatment of human HER2-overexpressing breast cancer cells. Food Chem. 2013, 141, 2591-2599. [CrossRef]

99. Wojtowicz, K.; Sterzyńska, K.; Świerczewska, M.; Nowicki, M.; Zabel, M.; Januchowski, R. Piperine targets different drug resistance mechanisms in human ovarian cancer cell lines leading to increased sensitivity to cytotoxic drugs. Int. J. Mol. Sci. 2021, 22, 4243. [CrossRef] [PubMed]

100. Narayana, D.; Sripal, R.; Chaluvadi, M.; Krishan, D. Bioflavonoids classification, pharmacological, biochemical effects and therapeutic POTENTIAL. Indian J. Pharmacol. 2001, 33, 2-6.

101. Ye, Q.; Liu, K.; Shen, Q.; Li, Q.; Hao, J.; Han, F.; Jiang, R.-W. Reversal of multidrug resistance in cancer by multi-functional flavonoids. Front. Oncol. 2019, 9, 487. [CrossRef]

102. Chearwae, W.; Anuchapreeda, S.; Nandigama, K.; Ambudkar, S.V.; Limtrakul, P. Biochemical mechanism of modulation of human P-glycoprotein (ABCB1) by curcumin I, II, and III purified from Turmeric powder. Biochem. Pharmacol. 2004, 68, $2043-2052$. [CrossRef]

103. Bisht, K.; Wagner, K.H.; Bulmer, A.C. Curcumin, resveratrol and flavonoids as anti-inflammatory, cyto- and DNA-protective dietary compounds. Toxicology 2010, 278, 88-100. [CrossRef]

104. Jurenka, J.S. Anti-inflammatory properties of curcumin, a major constituent of Curcuma longa: A review of preclinical and clinical research. Altern. Med. Rev. 2009, 14, 141-153. [PubMed] 
105. Aggarwal, B.B.; Kumar, A.; Bharti, A.C. Anticancer potential of curcumin: Preclinical and clinical studies. Anticancer Res. 2003, 23, 363-398.

106. Shishodia, S.; Singh, T.; Chaturvedi, M.M. Modulation of transcription factors by curcumin. Adv. Exp. Med. Biol. 2007, 595, 127-148. [CrossRef]

107. Banerjee, S.; Singh, S.K.; Chowdhury, I.; Lillard, J.W., Jr.; Singh, R. Combinatorial effect of curcumin with docetaxel modulates apoptotic and cell survival molecules in prostate cancer. Front. Biosci. 2017, 9, 235-245. [CrossRef]

108. Joshi, P.; Vishwakarma, R.A.; Bharate, S.B. Natural alkaloids as P-gp inhibitors for multidrug resistance reversal in cancer. Eur. J. Med. Chem. 2017, 138, 273-292. [CrossRef] [PubMed]

109. Limtrakul, P.; Chearwae, W.; Shukla, S.; Phisalphong, C.; Ambudkar, S.V. Modulation of function of three ABC drug transporters, P-glycoprotein (ABCB1), mitoxantrone resistance protein (ABCG2) and multidrug resistance protein 1 (ABCC1) by tetrahydrocurcumin, a major metabolite of curcumin. Mol. Cell. Biochem. 2007, 296, 85-95. [CrossRef]

110. Chearwae, W.; Wu, C.P.; Chu, H.Y.; Lee, T.R.; Ambudkar, S.V.; Limtrakul, P. Curcuminoids purified from turmeric powder modulate the function of human multidrug resistance protein 1 (ABCC1). Cancer Chemother. Pharmacol. 2006, 57, 376-388. [CrossRef]

111. Chearwae, W.; Shukla, S.; Limtrakul, P.; Ambudkar, S.V. Modulation of the function of the multidrug resistance-linked ATPbinding cassette transporter ABCG2 by the cancer chemopreventive agent curcumin. Mol. Cancer Ther. 2006, 5, 1995-2006. [CrossRef]

112. Wu, C.P.; Ohnuma, S.; Ambudkar, S.V. Discovering natural product modulators to overcome multidrug resistance in cancer chemotherapy. Curr. Pharm. Biotechnol. 2011, 12, 609-620. [CrossRef] [PubMed]

113. Odot, J.; Albert, P.; Carlier, A.; Tarpin, M.; Devy, J.; Madoulet, C. In vitro and in vivo anti-tumoral effect of curcumin against melanoma cells. Int. J. Cancer 2004, 111, 381-387. [CrossRef]

114. Gupta, S.C.; Patchva, S.; Koh, W.; Aggarwal, B.B. Discovery of curcumin, a component of golden spice, and its miraculous biological activities. Clin. Exp. Pharmacol. Physiol. 2012, 39, 283-299. [CrossRef]

115. Bhat, K.P.; Pezzuto, J.M. Cancer chemopreventive activity of resveratrol. Ann. N. Y. Acad. Sci. 2002, 957, 210-229. [CrossRef] [PubMed]

116. Bhat, K.P.L.; Kosmeder, J.W., 2nd; Pezzuto, J.M. Biological effects of resveratrol. Antioxid. Redox Signal. 2001, 3, 1041-1064. [CrossRef]

117. Mgbonyebi, O.P.; Russo, J.; Russo, I.H. Antiproliferative effect of synthetic resveratrol on human breast epithelial cells. Int. J. Oncol. 1998, 12, 865-869. [CrossRef]

118. Opipari, A.W.; Tan, L.; Boitano, A.E.; Sorenson, D.R.; Aurora, A.; Liu, J.R. Resveratrol-induced autophagocytosis in ovarian cancer cells. Cancer Res. 2004, 64, 696. [CrossRef] [PubMed]

119. Noel, B.; Singh, S.K.; Lillard, J.W., Jr.; Singh, R. Role of natural compounds in preventing and treating breast cancer. Front. Biosci. 2020, 12, 137-160. [CrossRef]

120. Singh, S.K.; Banerjee, S.; Acosta, E.P.; Lillard, J.W.; Singh, R. Resveratrol induces cell cycle arrest and apoptosis with docetaxel in prostate cancer cells via a p53/ p21WAF1/CIP1 and p27KIP1 pathway. Oncotarget 2017, 8, 17216-17228. [CrossRef]

121. Ko, J.-H.; Sethi, G.; Um, J.-Y.; Shanmugam, M.K.; Arfuso, F.; Kumar, A.P.; Bishayee, A.; Ahn, K.S. The role of resveratrol in cancer therapy. Int. J. Mol. Sci. 2017, 18, 2589. [CrossRef]

122. Carter, L.G.; D'Orazio, J.A.; Pearson, K.J. Resveratrol and cancer: Focus on in vivo evidence. Endocr.-Relat. Cancer 2014, 21, R209-R225. [CrossRef]

123. Nguyen, A.V.; Martinez, M.; Stamos, M.J.; Moyer, M.P.; Planutis, K.; Hope, C.; Holcombe, R.F. Results of a phase I pilot clinical trial examining the effect of plant-derived resveratrol and grape powder on Wnt pathway target gene expression in colonic mucosa and colon cancer. Cancer Manag. Res. 2009, 1, 25-37.

124. Howells, L.M.; Berry, D.P.; Elliott, P.J.; Jacobson, E.W.; Hoffmann, E.; Hegarty, B.; Brown, K.; Steward, W.P.; Gescher, A.J. Phase I randomized, double-blind pilot study of micronized resveratrol (SRT501) in patients with hepatic metastases-Safety, pharmacokinetics, and pharmacodynamics. Cancer Prev. Res. 2011, 4, 1419-1425. [CrossRef]

125. Singh, S.K.; Apata, T.; Gordetsky, J.B.; Singh, R. Docetaxel combined with thymoquinone induces apoptosis in prostate cancer cells via inhibition of the PI3K/AKT signaling pathway. Cancers 2019, 11, 1390. [CrossRef] [PubMed]

126. Aggarwal, B.B. Nuclear factor-kappaB: The enemy within. Cancer Cell 2004, 6, 203-208. [CrossRef] [PubMed]

127. Coussens, L.M.; Werb, Z. Inflammation and cancer. Nature 2002, 420, 860-867. [CrossRef] [PubMed]

128. Sethi, G.; Ahn, K.S.; Aggarwal, B.B. Targeting nuclear factor-kappa B activation pathway by thymoquinone: Role in suppression of antiapoptotic gene products and enhancement of apoptosis. Mol. Cancer Res. 2008, 6, 1059-1070. [CrossRef]

129. Ahmad, A.; Husain, A.; Mujeeb, M.; Khan, S.A.; Najmi, A.K.; Siddique, N.A.; Damanhouri, Z.A.; Anwar, F. A review on therapeutic potential of Nigella sativa: A miracle herb. Asian Pac. J. Trop. Biomed. 2013, 3, 337-352. [CrossRef]

130. Rahmani, A.H.; Alzohairy, M.A.; Khan, M.A.; Aly, S.M. Therapeutic implications of black seed and its constituent thymoquinone in the prevention of cancer through inactivation and activation of molecular pathways. Evidence-Based Complement. Altern. Med. 2014, 2014, 724658. [CrossRef]

131. Abukhader, M.M. Thymoquinone in the clinical treatment of cancer: Fact or fiction? Pharm. Rev. 2013, 7, 117-120. [CrossRef] [PubMed] 
132. Mostofa, A.G.M.; Hossain, M.K.; Basak, D.; Bin Sayeed, M.S. Thymoquinone as a potential adjuvant therapy for cancer treatment: Evidence from preclinical studies. Front. Pharmacol. 2017, 8, 295. [CrossRef]

133. Li, W.; Zhang, H.; Assaraf, Y.G.; Zhao, K.; Xu, X.; Xie, J.; Yang, D.H.; Chen, Z.S. Overcoming ABC transporter-mediated multidrug resistance: Molecular mechanisms and novel therapeutic drug strategies. Drug Resist. Updat. 2016, 27, 14-29. [CrossRef]

134. Yao, Y.; Zhou, Y.; Liu, L.; Xu, Y.; Chen, Q.; Wang, Y.; Wu, S.; Deng, Y.; Zhang, J.; Shao, A. Nanoparticle-based drug delivery in cancer therapy and its role in overcoming drug resistance. Front. Mol. Biosci. 2020, 7, 193. [CrossRef]

135. Venturoli, D.; Rippe, B. Ficoll and dextran vs. globular proteins as probes for testing glomerular permselectivity: Effects of molecular size, shape, charge, and deformability. Am. J. Physiol.-Renal Physiol. 2005, 288, F605-F613. [CrossRef] [PubMed]

136. Decuzzi, P.; Pasqualini, R.; Arap, W.; Ferrari, M. Intravascular delivery of particulate systems: Does geometry really matter? Pharm. Res. 2009, 26, 235-243. [CrossRef] [PubMed]

137. Wang, H.; Zhang, F.; Wen, H.; Shi, W.; Huang, Q.; Huang, Y.; Xie, J.; Li, P.; Chen, J.; Qin, L.; et al. Tumor- and mitochondria-targeted nanoparticles eradicate drug resistant lung cancer through mitochondrial pathway of apoptosis. J. Nanobiotechnol. 2020, 18, 8. [CrossRef]

138. Perrault, S.D.; Walkey, C.; Jennings, T.; Fischer, H.C.; Chan, W.C. Mediating tumor targeting efficiency of nanoparticles through design. Nano Lett. 2009, 9, 1909-1915. [CrossRef]

139. Yang, R.; Xu, J.; Xu, L.; Sun, X.; Chen, Q.; Zhao, Y.; Peng, R.; Liu, Z. Cancer cell membrane-coated adjuvant nanoparticles with mannose modification for effective anticancer vaccination. ACS Nano 2018, 12, 5121-5129. [CrossRef]

140. Chen, Y.; Gao, D.Y.; Huang, L. In vivo delivery of miRNAs for cancer therapy: Challenges and strategies. Adv. Drug Deliv. Rev. 2015, 81, 128-141. [CrossRef]

141. Kipp, J.E. The role of solid nanoparticle technology in the parenteral delivery of poorly water-soluble drugs. Int. J. Pharm. 2004, 284, 109-122. [CrossRef]

142. Zhang, L.; Chan, J.M.; Gu, F.X.; Rhee, J.-W.; Wang, A.Z.; Radovic-Moreno, A.F.; Alexis, F.; Langer, R.; Farokhzad, O.C. Selfassembled lipid-polymer hybrid nanoparticles: A robust drug delivery platform. ACS Nano 2008, 2, 1696-1702. [CrossRef]

143. Levit, S.; Tang, C. Polymeric nanoparticle delivery of combination therapy with synergistic effects in ovarian cancer. Nanomaterials 2021, 11, 1048. [CrossRef] [PubMed]

144. Lee, M.K.; Lim, S.J.; Kim, C.K. Preparation, characterization and in vitro cytotoxicity of paclitaxel-loaded sterically stabilized solid lipid nanoparticles. Biomaterials 2007, 28, 2137-2146. [CrossRef]

145. Qi, Z.; Yin, L.; Xu, Y.; Wang, F. Pegylated liposomal-paclitaxel induces ovarian cancer cell apoptosis via TNF-induced ERK/AKT signaling pathway. Mol. Med. Rep. 2018, 17, 7497-7504. [CrossRef]

146. Barani, M.; Bilal, M.; Sabir, F.; Rahdar, A.; Kyzas, G.Z. Nanotechnology in ovarian cancer: Diagnosis and treatment. Life Sci. 2021, 266, 118914. [CrossRef]

147. Xiao, X.; Zou, J.; Fang, Y.; Meng, Y.; Xiao, C.; Fu, J.; Liu, S.; Bai, P.; Yao, Y. Fisetin and polymeric micelles encapsulating fisetin exhibit potent cytotoxic effects towards ovarian cancer cells. BMC Complement. Altern. Med. 2018, 18, 91. [CrossRef]

148. Choi, E.; Lee, J.; Kwon, I.C.; Lim, D.-K.; Kim, S. Cumulative directional calcium gluing between phosphate and silicate: A facile, robust and biocompatible strategy for siRNA delivery by amine-free non-positive vector. Biomaterials 2019, 209, 126-137. [CrossRef]

149. Cai, L.; Xu, G.; Shi, C.; Guo, D.; Wang, X.; Luo, J. Telodendrimer nanocarrier for co-delivery of paclitaxel and cisplatin: A synergistic combination nanotherapy for ovarian cancer treatment. Biomaterials 2015, 37, 456-468. [CrossRef]

150. Yang, X.; Iyer, A.K.; Singh, A.; Milane, L.; Choy, E.; Hornicek, F.J.; Amiji, M.M.; Duan, Z. Cluster of differentiation 44 targeted hyaluronic acid based nanoparticles for MDR1 siRNA delivery to overcome drug resistance in ovarian cancer. Pharm. Res. 2015, 32, 2097-2109. [CrossRef] [PubMed]

151. Singh, S.K.; Lillard, J.W.; Singh, R. Reversal of drug resistance by planetary ball milled (PBM) nanoparticle loaded with resveratrol and docetaxel in prostate cancer. Cancer Lett. 2018, 427, 49-62. [CrossRef] [PubMed]

152. Gottesman, M.M.; Fojo, T.; Bates, S.E. Multidrug resistance in cancer: Role of ATP-dependent transporters. Nat. Rev. Cancer 2002, 2, 48-58. [CrossRef] [PubMed]

153. Darband, S.G.; Kaviani, M.; Yousefi, B.; Sadighparvar, S.; Pakdel, F.G.; Attari, J.A.; Mohebbi, I.; Naderi, S.; Majidinia, M. Quercetin: A functional dietary flavonoid with potential chemo-preventive properties in colorectal cancer. J. Cell. Physiol. 2018, 233, 6544-6560. [CrossRef]

154. Kalepu, S.; Nekkanti, V. Insoluble drug delivery strategies: Review of recent advances and business prospects. Acta Pharm. Sin. B 2015, 5, 442-453. [CrossRef]

155. Kapse-Mistry, S.; Govender, T.; Srivastava, R.; Yergeri, M. Nanodrug delivery in reversing multidrug resistance in cancer cells. Front. Pharmacol. 2014, 5, 159. [CrossRef]

156. Feng, S.T.; Li, J.; Luo, Y.; Yin, T.; Cai, H.; Wang, Y.; Dong, Z.; Shuai, X.; Li, Z.P. pH-sensitive nanomicelles for controlled and efficient drug delivery to human colorectal carcinoma LoVo cells. PLoS ONE 2014, 9, e100732. [CrossRef] [PubMed]

157. Singh, S.K.; Singh, S.; Lillard, J.W., Jr.; Singh, R. Drug delivery approaches for breast cancer. Int. J. Nanomed. 2017, 12, 6205-6218. [CrossRef] [PubMed]

158. Zhang, Y.; Huang, Y.; Li, S. Polymeric micelles: Nanocarriers for cancer-targeted drug delivery. AAPS PharmSciTech 2014, 15, 862-871. [CrossRef] 
159. Paris, J.L.; Vallet-Regí, M. Mesoporous silica nanoparticles for co-delivery of drugs and nucleic acids in oncology: A review. Pharmaceutics 2020, 12, 526. [CrossRef]

160. Chauhan, A.S. Dendrimers for drug delivery. Molecules 2018, 23, 938. [CrossRef]

161. Janaszewska, A.; Lazniewska, J.; Trzepiński, P.; Marcinkowska, M.; Klajnert-Maculewicz, B. Cytotoxicity of dendrimers. Biomolecules 2019, 9, 330. [CrossRef]

162. Mussi, S.V.; Sawant, R.; Perche, F.; Oliveira, M.C.; Azevedo, R.B.; Ferreira, L.A.; Torchilin, V.P. Novel nanostructured lipid carrier co-loaded with doxorubicin and docosahexaenoic acid demonstrates enhanced in vitro activity and overcomes drug resistance in MCF-7/Adr cells. Pharm. Res. 2014, 31, 1882-1892. [CrossRef]

163. Liu, M.; Chen, D.; Mukerabigwi, J.F.; Chen, S.; Zhang, Y.; Lei, S.; Luo, S.; Wen, Z.; Cao, Y.; Huang, X.; et al. Intracellular delivery of 10-hydroxycamptothecin with targeted nanostructured lipid carriers against multidrug resistance. J. Drug Target. 2016, 24, 433-440. [CrossRef] [PubMed]

164. Halbur, C.; Choudhury, N.; Chen, M.; Kim, J.H.; Chung, E.J. siRNA-conjugated nanoparticles to treat ovarian cancer. SLAS Technol. 2019, 24, 137-150. [CrossRef] [PubMed]

165. Salzano, G.; Navarro, G.; Trivedi, M.S.; De Rosa, G.; Torchilin, V.P. Multifunctional polymeric micelles co-loaded with anti-survivin siRNA and paclitaxel overcome drug resistance in an animal model of ovarian cancer. Mol. Cancer Ther. 2015, 14, 1075-1084. [CrossRef]

166. Zou, S.; Cao, N.; Cheng, D.; Zheng, R.; Wang, J.; Zhu, K.; Shuai, X. Enhanced apoptosis of ovarian cancer cells via nanocarriermediated codelivery of siRNA and doxorubicin. Int. J. Nanomed. 2012, 7, 3823-3835. [CrossRef]

167. Zaffaroni, N.; Daidone, M.G. Survivin expression and resistance to anticancer treatments: Perspectives for new therapeutic interventions. Drug Resist. Updat. 2002, 5, 65-72. [CrossRef]

168. Zaffaroni, N.; Pennati, M.; Colella, G.; Perego, P.; Supino, R.; Gatti, L.; Pilotti, S.; Zunino, F.; Daidone, M.G. Expression of the anti-apoptotic gene survivin correlates with taxol resistance in human ovarian cancer. Cell. Mol. Life Sci. 2002, 59, 1406-1412. [CrossRef] [PubMed]

169. Singh, R.; Lillard, J.W. Nanoparticle-based targeted drug delivery. Exp. Mol. Pathol. 2009, 86, 215-223. [CrossRef]

170. Persano, S.; Das, P.; Pellegrino, T. Magnetic nanostructures as emerging therapeutic tools to boost anti-tumour immunity. Cancers 2021, 13, 2735. [CrossRef] [PubMed]

171. Singh, S.K.; Gordetsky, J.B.; Bae, S.; Acosta, E.P.; Lillard, J.W., Jr.; Singh, R. Selective targeting of the hedgehog signaling pathway by PBM nanoparticles in docetaxel-resistant prostate cancer. Cells 2020, 9, 1976. [CrossRef]

172. Singh, S.K.; Lillard, J.W.; Singh, R. Abstract 4665: Neurotensin receptor-based targeted delivery of thymoquinone for non-small cell lung cancer. Cancer Res. 2018, 78, 4665. [CrossRef] 